\title{
Enhancement of Organics Removal by an Integrated Nonwoven Media Biofilter-submerged Membrane Adsorption Hybrid System
}

\author{
W. S. Guo ${ }^{1}$, W. Xing ${ }^{2}$, H. H. Ngo ${ }^{3 *}$, A. Y. J. Hu ${ }^{4}$, C. G. Palmer ${ }^{5}$ \& R. Zhang ${ }^{6}$ \\ ${ }^{1,2,3,5 \& 6}$ Faculty of Engineering, University of Technology, Sydney (UTS), PO Box 123, Broadway, NSW 2007, \\ Australia \\ ${ }^{4}$ KNH Enterprise Co. Ltd., Taiwan, 1-2 Yuantou, Baoyuan Village, Tainan 72546, Taiwan
}

\begin{abstract}
This study aims to investigate the feasibility of using nonwoven fabric material (NB) as bedding material in a circulating fluidized bed biofilter (FBB), coupling with a submerged membrane adsorption hybrid system (SMAHS) to treat high strength synthetic wastewater containing refractory organic pollutants. The results show that the NBFBB could remove major part of the organic pollutants at relatively low influent feeding rate of 10 and $20 \mathrm{~mL} / \mathrm{min}$ with the bed depth of $25 \mathrm{~cm}$ and minimum recirculation rate of $50 \%$. The integrated NB-FBB-SMAHS system exhibited excellent DOC and nutrient removal with the bed depth of $45 \mathrm{~cm}$ and $50 \%$ recirculation rate. At the NB. FBB influent feeding rate of $50 \mathrm{~mL} / \mathrm{min}$, the system removed more than $96 \%$ of DOC, $100 \%$ of $\mathrm{NH}_{4}-\mathrm{N}_{\text {and }} 84.2 \%$ $\mathrm{PO}_{4}-\mathrm{P}$ with a low TMP development of $9.5 \mathrm{kPa}$. Molecular weight (MW) distributions also indicated that the system could eliminate dissolved organic pollutants range from 90 to 40200 Daltons.
\end{abstract}

Keywords: Aerobic fluidized bed biofilter, membrane hybrid system, nonwoven media, refractory organic matter, adsorption

\subsection{INTRODUCTION}

Municipal wastewater contains wide range of contaminants which can be classified as particulate substances, biodegradable organic matter (BOM) and refractory organic substances (ROS). The major fraction of ROS attributes to humic substances (HS), which are complex macromolecular products of the chemical and biological degradation of plant and animal residues, including lignin, carbohydrates and proteins $[1,2]$. HS (MW range from 1,000-100,000 Daltons) are slowbiodegradable and hardly removed by biological secondary treatment process [3]. They are also the major challenge for membrane process due to organic fouling. Physico-chemical processes (such as coagulation, adsorption and oxidation) are the

\footnotetext{
"Corresponding to: H. H. Ngo (email: h.ngo@uts.edu.au)
}

common treatment for removing ROS from wastewater. However, these processes are generally of higher cost and the sludge produced may require extensive treatment before disposal [4]. Therefore, development of new technology for enhancing recalcitrant organics removal is essential.

The fluidized bed bioreactor (FBBR) (also called moving-bed biofilm reactor (MBBR) or suspended-carrier biofilm reactor (SCBR) has attracted considerable interest as an alternative to the conventional suspended growth and fixed-film wastewater treatment processes due to its high performance efficiency. Comparing with the conventional suspended-growth activated sludge process, it has several advantages such as higher biomass concentration, co-existence of aerobic and anoxic metabolic activity within the same system, lower hydraulic retention time (HRT), lower sensitivity to toxicity effect as well as to other adverse environmental conditions, small foot print 
and minimum up-grading cost for existing wastewater treatment plants $[.5,6]$. In this biofiltration system, the pollutants could be removed from the wastewater by biological degradation incorporated into the attached microbial biomass, adsorbed to the bedding material or to the microbial film. Thus, the bedding material plays a major role in governing microbial attachment as the degree of porosity is an important factor in the adsorption of microorganisms to the bedding material. The bedding material with high porosity has a high void space inside allows the microorganisms to attach under low shear condition, while the fluid outside the bedding material can be moving at a high speed [7].

Nonwoven (NW) fabric material is composed of a random network of overlap fibers creating multiple connected pores through which the fluid can flow. The material is non reactive and can be used in specific wastewater treatment process. It has many outstanding properties such as lightweight and compressible (easy to transport), high hydraulic conductivity, controllable pore size distribution and flexible design of large surface to volume ratio for biological attachment. The most essential element of NW material is that it can offer cheaper capital cost $[8,9]$.

The approach of this study is to develop an aerobic nonwoven media fluidized bed biofilter (NB-FBB) in conjunction with a submerged membrane adsorption hybrid system (SMAHS) to enhance the organic removal from a high strength synthetic wastewater. The performance of this integrated system was assessed in terms of the removal efficiency of dissolved organic carbon (DOC), ammonium nitrogen $\left(\mathrm{NH}_{4}-\mathrm{N}\right)$, orthophosphate $\left(\mathrm{PO}_{4}-\mathrm{P}\right)$, transmembrane pressure (TMP) and molecular weight distribution.

Table 1 Constituents of the synthetic wastewater

\begin{tabular}{lcc}
\hline Compounds & Molecular weight & $\begin{array}{c}\text { Concentration } \\
\text { (mg/L) }\end{array}$ \\
\hline Organics and nutrients & $(\mathrm{g} / \mathrm{mol})$ & 280 \\
Glucose $\left(\mathrm{C}_{6} \mathrm{H}_{12} \mathrm{O}_{6}\right)$ & 180.0 & 72 \\
Ammonium sulfate $\left(\left(\mathrm{NH}_{4}\right)_{2} \mathrm{SO}_{4}\right)$ & 132.1 & 13.2 \\
Potassium phosphate $\left(\mathrm{KH}_{2} \mathrm{PO}_{4}\right)$ & 136.1 & \\
Trace nutrients & & 0.368 \\
Calcium chloride $\left(\mathrm{CaCl}_{2} \cdot 2 \mathrm{H}_{2} \mathrm{O}\right)$ & 147.0 & 5.07 \\
Magnesium sulfate $\left(\mathrm{MgSO}_{4} \cdot 7 \mathrm{H}_{2} \mathrm{O}\right)$ & 246.5 \\
Manganese chloride $\left(\mathrm{MnCl}_{2} \cdot 4 \mathrm{H}_{2} \mathrm{O}\right)$ & 197.9 & 0.275 \\
Zinc sulfate $\left(\mathrm{ZnSO} \mathrm{O}_{4} \cdot 7 \mathrm{H}_{2} \mathrm{O}\right)$ & 287.5 & 0.44 \\
Ferric chloride anhydrous $\left(\mathrm{FeCl}_{3}\right)$ & 162.2 & 1.45 \\
Cupric sulfate $\left(\mathrm{CuSO} \cdot 5 \mathrm{H}_{2} \mathrm{O}\right)$ & 249.7 & 0.391 \\
Cobalt chloride $\left(\mathrm{CoCl} \cdot 6 \mathrm{H}_{2} \mathrm{O}\right)$ & 237.9 & 0.42 \\
Sodium molybdate dihydrate $\left(\mathrm{Na}_{2} \mathrm{MoO}_{4} \cdot 2 \mathrm{H}_{2} \mathrm{O}\right)$ & 242.0 & 1.26 \\
Yeast extract & & 30 \\
Recalcitrant organics & & \\
Peptone & $(\mathrm{Daltons})$ & 2.7 \\
Humic acid & 3426512880 & 4.2 \\
Tannic acid & 1543298 & 4.2 \\
(Sodium) lignin sulfonate & 6343 & 2.4 \\
Sodium lauryle sulphate & 12120 & 0.94 \\
Acacia gum powder & 34265 & 5.7 \\
Arabic acid (polysaccharide) & 925256 & 5 \\
\hline
\end{tabular}




\subsection{METHODS/THEORY}

\subsection{Wastewater}

The experiments were conducted using a high strength synthetic wastewater (primary effluent) containing recalcitrant organic pollutants. The characteristics of the synthetic wastewater are shown in Table 1. The wastewater composes of BOM such as glucose and ROS such as humic acid, tannic acid, lignin, polysaccharide, proteins and other high molecular weight carbohydrates $[10$, 11]. The synthetic wastewater has DOC of 130$145 \mathrm{mg} / \mathrm{L}, \mathrm{NH}_{4}-\mathrm{N}$ of $15-20 \mathrm{mg} / \mathrm{L}$ and $\mathrm{PO}_{4}-\mathrm{P}$ of $3.5-4.0 \mathrm{mg} / \mathrm{L}$.

\subsection{Integrated Experimental Set-up NB- FBB-SMAHS}

The schematic diagram of the integrated NB-FBBSMAHS used in this study is shown in Figure 1. The FBB consists of a Perspex column with a height of $80 \mathrm{~cm}$ and an internal diameter of 4.5 $\mathrm{cm}$. Air was supplied from the diffuser from the bottom of the $\mathrm{FBB}$ at a constant rate of $3 \mathrm{~L} / \mathrm{min}$. Nonwoven Bioweb ${ }^{\circledR}$ (NB, KNH Enterprise Co. Ltd., Taiwan) was used as bedding media in the aerobic FBB. NB was acclimatized to synthetic wastewater before using and the biomass attached on NB was $679.33 \mathrm{mg} / \mathrm{g}_{\text {bioweb. }}$. According to different recirculation rates, part of the effluent was recycled within the FBB by an recirculation pump, while the other part of effluent was delivered into the membrane tank by gravity force using a value to control the feed rate while membrane permeate rate was controlled by a suction pump (Figure 1). As shown in the figure, the polyethylene hollow fiber membrane module has a pore size of $0.1 \mu \mathrm{m}$ and surface area of $0.1 \mathrm{~m}^{2}$. A pressure gauge was used to measure the transmembrane pressure (TMP) and a soaker hose air diffuser was used to maintain a high air flow rate $(9 \mathrm{~L} / \mathrm{min})$. After each experiment, membrane was cleaned by chemical cleaning method. A coal based powdered activated carbon (PAC, Activated Carbon Technologies Pty Ltd, Australia) was used with a

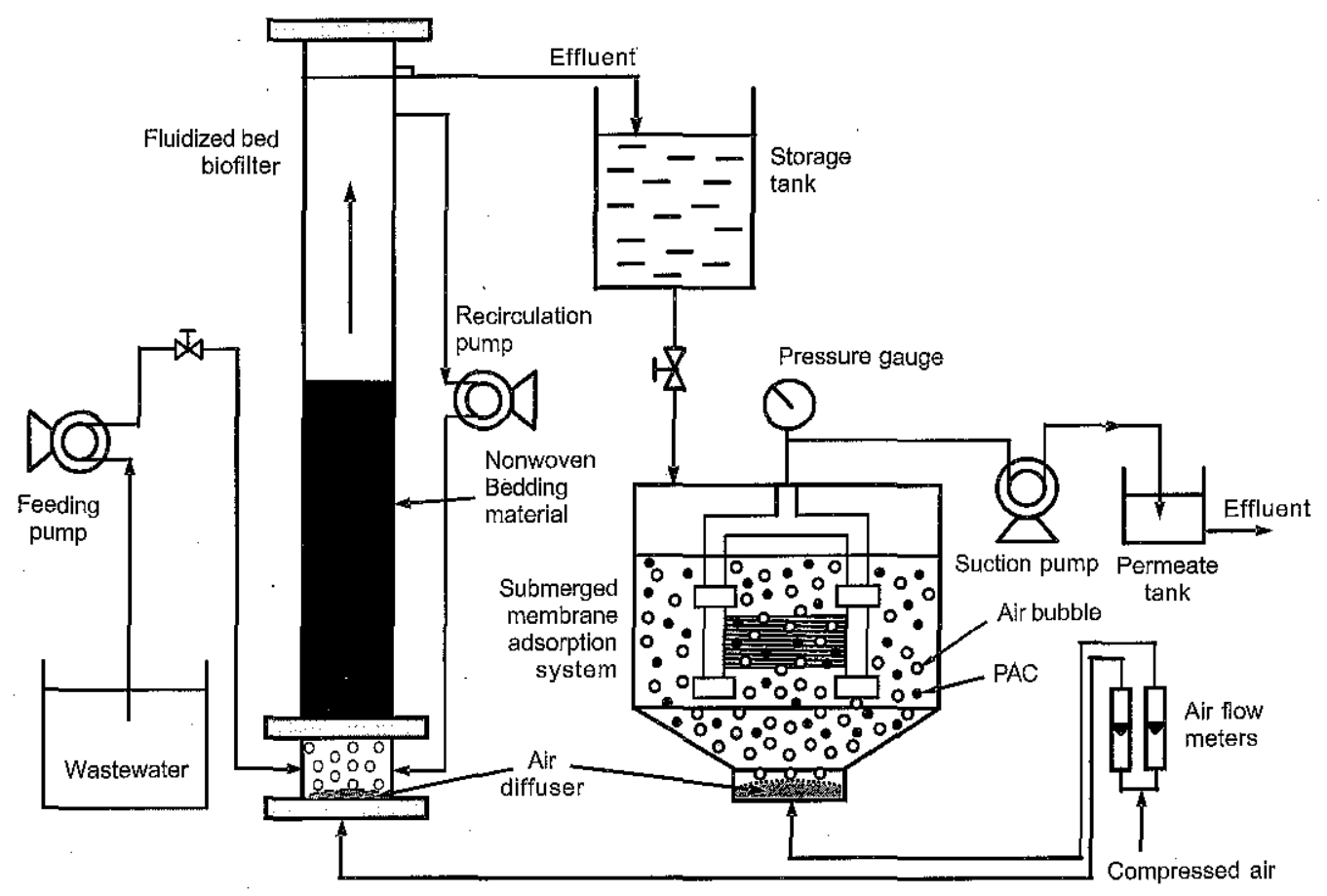

Figure 1 Experimental set-up of NB-FBB-SMAHS 
dose of $2 \mathrm{~g} / \mathrm{L}_{\text {tank }}$ (total $12 \mathrm{~g}$ ), which has a surface area of $1300 \mathrm{~m}^{2} / \mathrm{g}$. During each 8-hour experiment, only $12 \mathrm{~g}$ PAC was added to the $6 \mathrm{~L}$ membrane reactor tank and one hour pre-adsorption was applied to reduce the initial organic loading to membrane. The submerged membrane system was operated at a high filtration rate (membrane filtration flux maintained at $30 \mathrm{~L} / \mathrm{m}^{2} . \mathrm{h}$ ) for continuous 8 hours without any backwash. There was no further addition of PAC during the experimental period.

\section{3 : Analysis}

DOC of the influent and effluent was measured using the Analytikjena Multi N/C 2000. The measuring of biomass (monitored as mixed liquor volatile suspended solids, MLVSS) was measured according to Standard Methods [12]. For measuring biomass, three samples were talken each time and the average values were then calculated. $\mathrm{NH}_{4}-\mathrm{N}$ and $\mathrm{PO}_{4}-\mathrm{P}$ were analyzed by photometric method called Spectroquant $\$$ Cell Test using Merck NOVA 60. High pressure size exclusion chromatography (HPSEC; Shimadze, Corp., Japan) with a. SEC column (Protein-pak 125, Waters, Milford, USA) was used to determine the molecular weight (MW) distributions of dissolved organics. The equipment was calibrated using the standards of MW of various polystyrene sulphonates (PSS: 210, 1800, 4600, 8000 and 18000). The MW distribution results were analysed using the response $(\mathrm{mV})$ data of HPSEC with elapsed time.

\subsection{RESULTS AND DISCUSSIONS}

\subsection{Performance of NB-FBB in Treating Biodegradable Wastewater}

The feasibility of NB-FBB was evaluated in a series of short-term experiments, which were carried out to optimize the performance of NB-FBB with different influent feeding rates and recirculation rates $(20 \%, 50 \%, 80 \%$ and $100 \%)$ using synthetic wastewater containing BOM only. The depth of $\mathrm{NB}$ bed was $25 \mathrm{~cm}$ and expanded to $30 \mathrm{~cm}$ during the experiments. Table 2 summarises the average effluent quality of NB-FBB during each 6-hour experiment: At low influent feeding rates of 10 $\mathrm{mL} / \mathrm{min}$ and $20 \mathrm{~mL} / \mathrm{min}$, the results show that the DOC removal efficiencies were similar $(>86.5 \%$ and $>76.0 \%$ respectively) with all four different recirculation rates. At higher feeding rate of 50 $\mathrm{mL} / \mathrm{min}$, the system could only provide better organic removal $(55 \%)$ with the minimum recirculation rate of $50 \%$ (Table 2). Besides, the system also achieved high ammonium nitrogen $\left(\mathrm{NH}_{4}-\mathrm{N}\right)$ removal $(>90 \%)$ in all cases when recirculation rate was higher than $20 \%$. In case of $20 \%$ recirculation rate, $\mathrm{NH}_{4}-\mathrm{N}$ removal efficiency reduced to $85.5 \%$ at the feeding rate of $50 \mathrm{~mL} /$ min. However, the orthophosphate $\left(\mathrm{PO}_{4}-\mathrm{P}\right)$ removal was highly related to influent feeding rate and the recirculation rate. The lower feeding rate with higher recirculation rate could lead to better $\mathrm{PO}_{4}-\mathrm{Premoval}$. For instance, with the recirculation rates of $80 \%$ and $20 \%$, the $\mathrm{PO}_{4}-\mathrm{P}$ removal decrease from $75.5 \%$ and $68.1 \%$ (influent feeding rate of

Table 2 The average effluent quality of NB.FBB at different influent feeding rates and recirculation rates (Influent DOC $=130-145 \mathrm{mg} / \mathrm{L} ; \mathrm{NH}_{4}-\mathrm{N}=15-20 \mathrm{mg} / \mathrm{L}$ )

\begin{tabular}{|c|c|c|c|c|c|c|}
\hline \multirow{2}{*}{$\begin{array}{l}\text { Recirculation } \\
\text { rate }(\%)\end{array}$} & \multicolumn{2}{|c|}{$10 \mathrm{~mL} / \mathrm{min}$ (IFR) } & \multicolumn{2}{|c|}{$20 \mathrm{~mL} / \mathrm{min}$ (IFR) } & \multicolumn{2}{|c|}{$50 \mathrm{~mL} / \mathrm{min}$ (IFR) } \\
\hline & $\begin{array}{c}\text { DOC RE } \\
(\%)\end{array}$ & $\begin{array}{c}\mathbf{N H}_{4}-\mathbf{N} \mathbf{R E} \\
(\%)\end{array}$ & $\begin{array}{c}\text { DOC RE } \\
(\%)\end{array}$ & $\begin{array}{c}\mathrm{NH}_{4}-\mathrm{N} \mathrm{RE} \\
(\%)\end{array}$ & $\begin{array}{c}\text { DOC RE } \\
(\%)\end{array}$ & $\begin{array}{c}\mathrm{NH}_{4} \cdot \mathbf{N} \text { RE } \\
(\%)\end{array}$ \\
\hline 100 & 88.8 & 99.2 & 77.6 & 95.7 & 62.8 & 94.4 \\
\hline 80 & 87.6 & 97.4 & 76.0 & 93.9 & 56.0 & 93.5 \\
\hline 50 & 88.2 & 93.2 & 76.0 & 90.4 & 54.8 & 91.9 \\
\hline 20 & 86.5 & 91.6 & 76.6 & 90.0 & 44.8 & 85.5 \\
\hline
\end{tabular}

IFR: influent feeding rate

$\mathrm{RE}$ : removal efficiency 
$10 \mathrm{~mL} / \mathrm{min}$ ) to $24.9 \%$ and $5.5 \%$ (influent feeding rate of $50 \mathrm{~mL} / \mathrm{min}$ ) respectively. According to the results, $50 \%$ was selected as the minimum recirculation rate for running the NB-FBB as pretreatment to SMAHS.

\subsection{Performance of NB-FBB-SMAHS}

NB-FBB was then connected to the SMAHS as a pretreatment unit to treat the wastewater containing both BOM and ROS at different influent feeding rates of $30 \mathrm{~mL} / \mathrm{min}, 50 \mathrm{~mL} / \mathrm{min}$ and 70 $\mathrm{mL} / \mathrm{min}$ with the same recirculation rate of $50 \%$ (NB-FBB filtration rates of $15 \mathrm{~mL} / \mathrm{min}, 25 \mathrm{~mL} /$ $\mathrm{min}$ and $35 \mathrm{~mL} / \mathrm{min}$ respectively). The depth of NB bed was increased to $45 \mathrm{~cm}$ height and expanded to $50 \mathrm{~cm}$ during the experiment. The biofilter was operated at an empty bed contact time (EBCT) of 27, 16 and 11 minutes when the influent feeding rates varied from $30 \mathrm{~mL} / \mathrm{min}$ to $70 \mathrm{~mL} / \mathrm{min}$. The collected effluent from NB-FBB was employed as the feeding to SMAHS for removing residual organics. After NB-FBB pretreatment, $90.6 \%$ and $90.5 \%$ DOC were eliminated at the NB-FBB filtration rates of $15 \mathrm{~mL} / \mathrm{min}$ and $25 \mathrm{~mL} / \mathrm{min}$ respectively, while only $67.66 \%$ of DOC was removed at the filtration rate of $35 \mathrm{~mL} /$ min. The overall DOC removal of NB-FBB-
SMAHS as shown in Figure 2 indicated that the superior treated water quality was achieved at FBB filtration rates of 15 and $25 \mathrm{~mL} / \mathrm{min}$ (effluent DOC $<1 \mathrm{mg} / \mathrm{L}$ and effluent DOC $<2 \mathrm{mg} / \mathrm{L}$ respectively), whereas $80 \%$ of organic matter was removed by the integrated system at higher filtration rate of $35 \mathrm{~mL} / \mathrm{min}$. Thus, this integrated system could successfully remove BOM and ROS with EBCT of more than 16 minutes.

MWD measurement was carried out to show which MW range of organic matter could be removed by the NB-FBB-SMAHS. The synthetic wastewater consists of dissolved organic matters with the MW fractions of $40200,3600,2250,1270$, 670,400 and 90 Daltons. The NB-FBB could eliminate the major part of the large MW fraction of 40200 and small MW fraction of 90 Daltons. Nevertheless, due to the relatively short contact time and recalcitrant organics present in the wastewater which biological process could not remove, the MW fractions from 400 to 3600 could not be removed completely from the wastewater (Figure 3). After SMAHS, most of the remaining MW fractions were eliminated. However, a small portion of low MW molecules (670-2250 Daltons) still remained in the effluent. The results exhibited NB-FBB was excellent in removing large MW dissolved organic matters while PAC adsorption

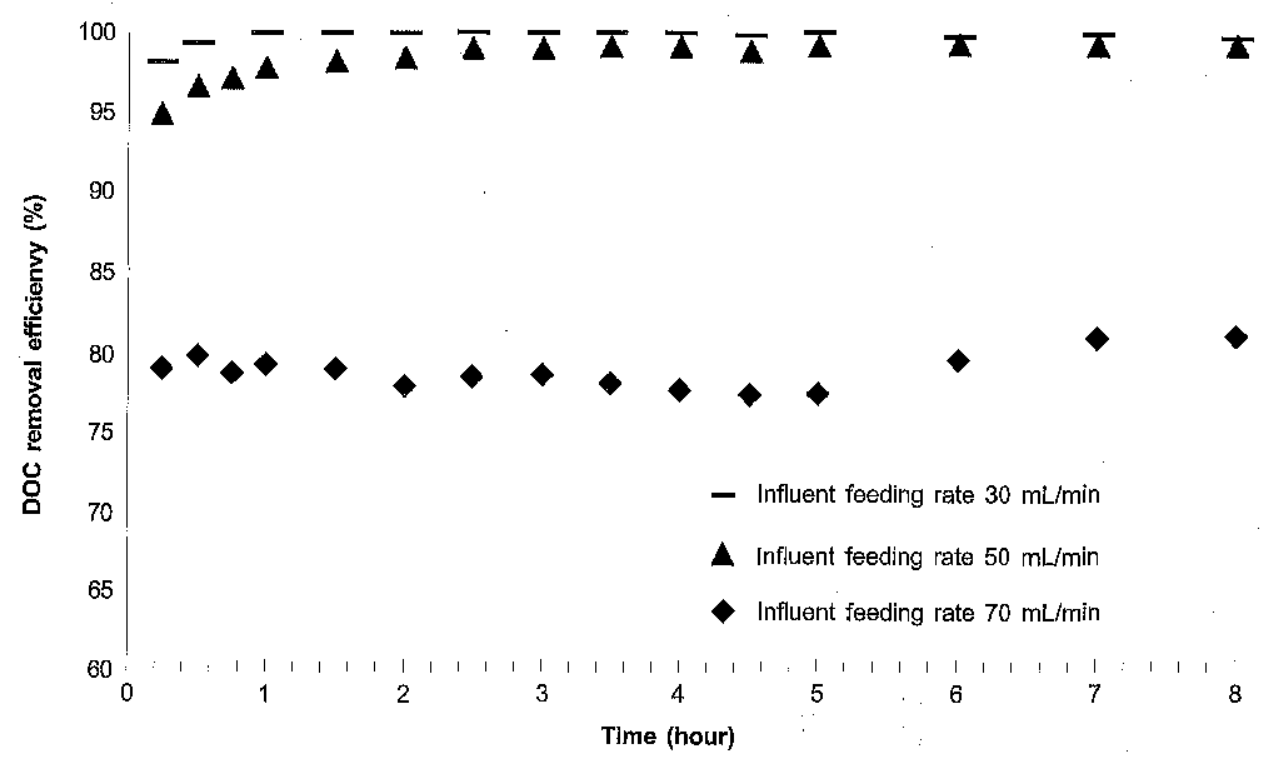

Figure 2 DOC removal efficiency of NB-FBB-SMAHS with recirculation rate of 50 


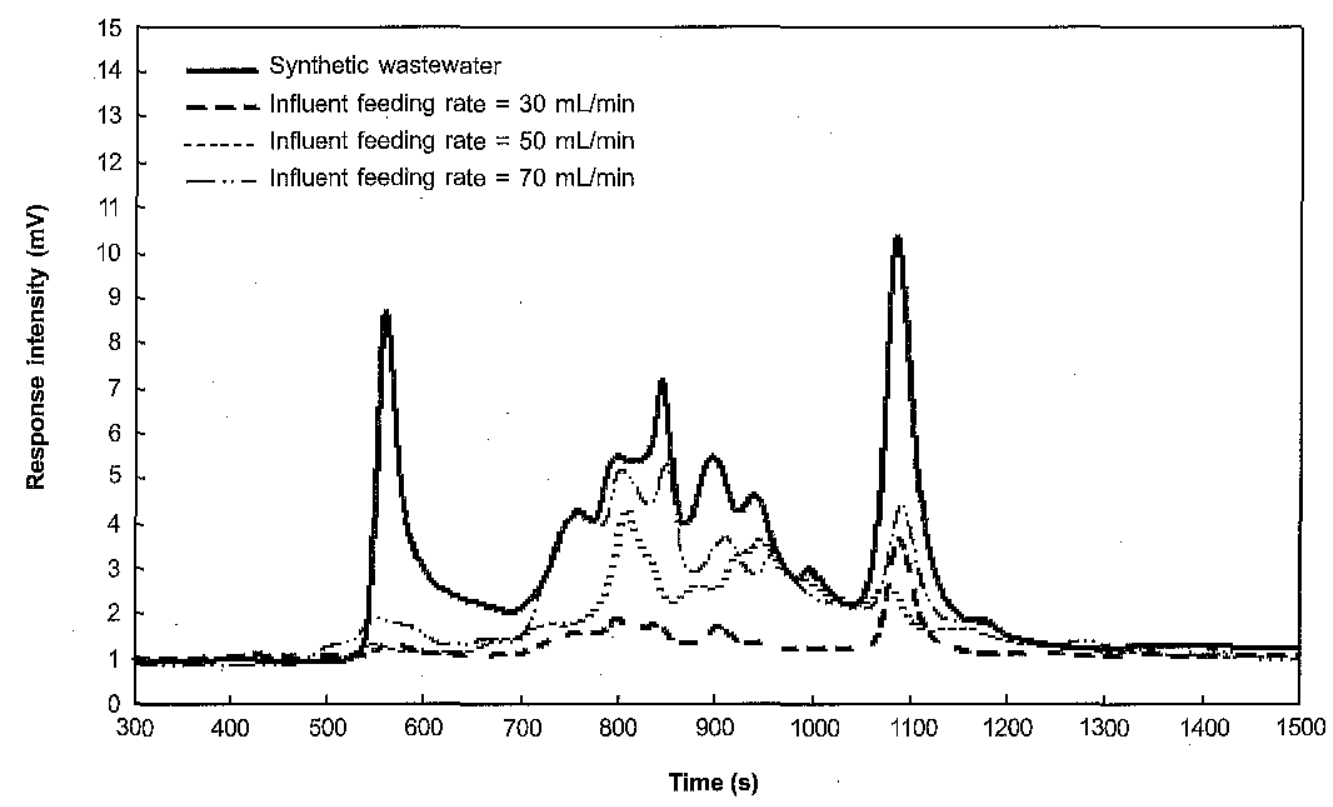

Figure 3 MWD of dissolved organic matters (synthetic wastewater and NB-FBB effluent)

Table $3 \mathrm{NH}_{4}-\mathrm{N}$ and $\mathrm{PO}_{4}-\mathrm{P}$ removal efficiency after 8-hour operation of NB-FBB-SMAHS (Influent $\mathrm{NH}_{4}-\mathrm{N}=15-20 \mathrm{mg} / \mathrm{L}$ and $\mathrm{PO}_{4}-\mathrm{P}=3.5-4.0 \mathrm{mg} / \mathrm{L}$ )

\begin{tabular}{|c|c|c|c|c|c|c|}
\hline \multirow{2}{*}{ Parameters } & \multicolumn{2}{|c|}{$30 \mathrm{~mL} / \mathrm{min}$ (IFR) } & \multicolumn{2}{|c|}{$50 \mathrm{~mL} / \mathrm{min}$ (IFR) } & \multicolumn{2}{|c|}{$70 \mathrm{~mL} / \mathrm{min}(\mathrm{IFR})$} \\
\hline & $\begin{array}{c}\text { Effluent } \\
(\mathrm{mg} / \mathrm{L})\end{array}$ & RE $(\%)$ & $\begin{array}{c}\text { Effluent } \\
(\mathrm{mg} / \mathrm{L})\end{array}$ & $\operatorname{RE}(\%)$ & $\begin{array}{l}\text { Effluent } \\
\text { (mg/L) }\end{array}$ & RE (\%) \\
\hline $\mathrm{NH}_{4}-\mathrm{N}$ & 0.5 & 96.8 & 0 & 100 & 2.28 & 88.1 \\
\hline $\mathrm{PO}_{4}-\mathrm{P}$ & 0.45 & 87.1 & 0.61 & 84.2 & 2.09 & 41.2 \\
\hline
\end{tabular}

IFR: influent feeding rate

RE: removal efficiency

could help for removing the small MW part. The MWD results could correspond to the DOC removal of the NB-FBB-SMAHS.

Table 3 presents the nutrient removal in the NB-FBB-SMAHS after 8-hour operation. FBB filtration rates of 15 and $25 \mathrm{~mL} / \mathrm{min}$ resulted in high removal efficiency of $\mathrm{NH}_{4}-\mathrm{N}(96.8 \%$ and 100 $\%$ respectively) with the effluent $\mathrm{NH}_{4}-\mathrm{N}$ of less than $0.5 \mathrm{mg} / \mathrm{L}$, which indicated nearly completed nitrification. Nevertheless, the highest influent feeding rate of $70 \mathrm{~mL} / \mathrm{min}$ led to lowest percentage reduction of $\mathrm{NH}_{4}-\mathrm{N}(88.1 \%)$. Similar trend was observed in $\mathrm{PO}_{4}-\mathrm{P}$ removal. The influent feeding rates of 30 and $50 \mathrm{~mL} / \mathrm{min}$ gained better $\mathrm{PO}_{4}-\mathrm{P}$ removal (>84\%). However, higher influent feeding rate could affect $\mathrm{PO}_{4}-\mathrm{P}$ removal (only $41.2 \%$ at influent feeding rate of $70 \mathrm{~mL} / \mathrm{min}$ ) due to the short EBCT of 11 minutes.

The TMP development was measured to investigate the membrane fouling of NB-FBB as pretreatment to SMAHS. The best influent feeding rate $(30 \mathrm{~mL} / \mathrm{min})$ for best $\mathrm{DOC}$ and nutrient removal did not show a good result of TMP. TMP in this case increased from $2 \mathrm{kPa}$ to $32 \mathrm{kPa}$ within the 8-hour run (Figure 4). On the other hand, the TMP development only increased 9.5 and $6.5 \mathrm{kPa}$ at the influent feeding rates of 50 and $70 \mathrm{~mL} / \mathrm{min}$ respectively. This is due to at $30 \mathrm{~min} / \mathrm{L}$ feeding 


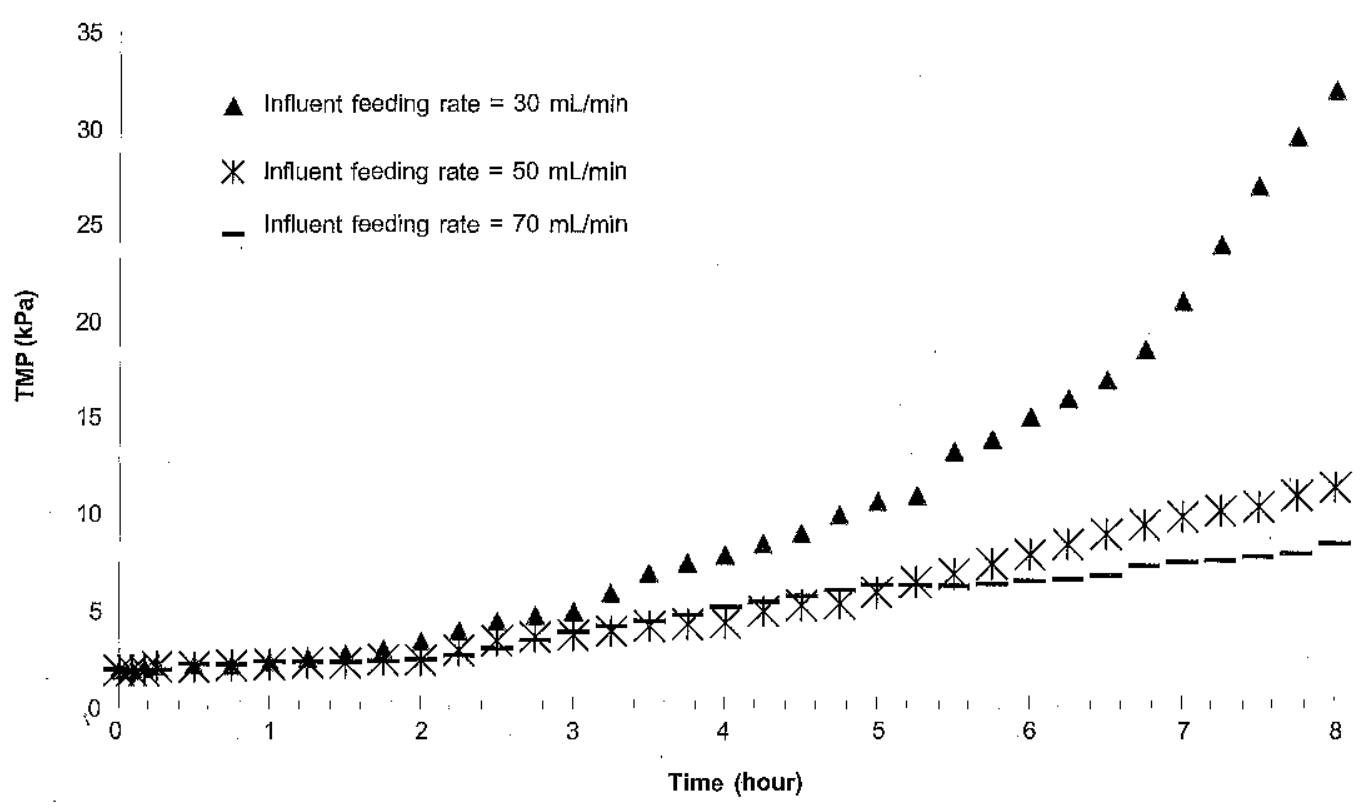

Figure 4 TMP development of submerged membrane with recirculation rate $50 \%$

rate, the longer EBCT of 27 min could stimulate more biomass growth within the bioweb than the other two cases. Thus, some excess biomass was rushed out from NB-FBB because of aeration and caused high turbidity of the effluent. The results indicated that the NB-FBB effluent turbidity was up to $30.5 \mathrm{NTU}$ at an influent feeding rate of 30 $\mathrm{mL} / \mathrm{min}$ compared to other two flow rates $(12.5$ $\mathrm{NTU}$ at $50 \mathrm{~mL} / \mathrm{min}$ and $3.3 \mathrm{NTU}$ at $70 \mathrm{~mL} / \mathrm{min}$ ), which could cause higher TMP development when the membrane was operated at high filtration flux without any backwash. Therefore, to further optimize the long-term operation conditions for NB-FBB, it is important to find a balance among the EBCT, biomass growth within the bed and aeration rate.

\subsection{CONCLUSIONS}

An aerobic fluidized bed biofilter employing nonwoven bedding material was evaluated to treat a high strength synthetic wastewater containing BOM and ROS. The results showed that the NBFBB could lead to high DOC $(>76 \%)$ and ammonium nitrogen $(>90 \%)$ removal efficiency at the influent feeding rates of $10 \mathrm{~mL} / \mathrm{min}$ and
$20 \mathrm{~mL} / \mathrm{min}$ with the minimum recirculation rate of $50 \%$. When the NB-FBB was used as pretreatment unit to SMAHS at a constant membrane filtration flux of $30 \mathrm{~L} / \mathrm{m}^{2} . h$, the superior treated water quality with lowest TMP development was achieved at NB-FBB influent feeding rate of $50 \mathrm{~mL} / \mathrm{min}$ (effluent DOC $<2 \mathrm{mg} / \mathrm{L}, \mathrm{NH}_{4}-\mathrm{N}$ removal $>96.8 \%, \mathrm{PO}_{4}-\mathrm{P}$ removal $>84 \%$ and $\mathrm{TMP}$ development of $9.5 \mathrm{kPa}$ ). The NB-FBB-SMAHS also could remove the major fractions of dissolved organic pollutants range from 90 to 40200 Daltons. EBCT and aeration rate applied to the NB-FBB are the main factors govern the membrane fouling during the high rate operation.

\section{ACKNOWLEDGMENT}

This research was funded by Australian Research Council (ARC) Industry Linkage Grant (LP0775149). The authors are also grateful for the support of UTS Chancellor's Postdoctoral Research Fellowship and UTS Early Career Researcher Grants, as well as KNH Enterprise Co. Ltd., Taiwan and Activated Carbon Technologies Pty Ltd, Australia. 


\section{REFERENCES}

[1] Seo, G.T., S. Ohgaki, and Y. Suzulki. 1997. Sorption Characteristics of Biological Powdered Activated Carbon in BPAC-MF (biological powdered activated carbonmicrofiltration) System for Refractory Organic Removal. Water Science and Technology. 35(7): 163-170.

[2] Owen, D.M., G.L. Amy, Z.K. Chowdhury, R. Paode, G. McCoy, and K. Viscosil. 1995. NOM Characterization and Treatability. Journal of AWWA. 87(1): 46-63.

[3] Manka, J., and M. Rebhun. 1982. Organic Groups and Molecular Weight Distribution in Tertiary Effluents and Renovated Waters. Water Research. 16: 399-403.

[4] Basu, O.D., and P.M. Huck. 2005. Impact of Support Media in an Integrated Biofiltersubmerged Membrane System. Water Research. 39: 4220-4228.

[5] "Patel, A., J. Zhu, and G. Nalkhla. 2006. Simultaneous Carbon, Nitrogen and Phosphorous Removal from Municipal Wastewater in a Circulating Fluidized Bed Bioreactor. Chemosphere. 65: 1103-1112.

[6] Loukidou, M.X., and A.I. Zouboulis. 2001. Comparison of Two Biological Treatment Processes using Attached-growth Biomass for Sanitary Landfill Leachate Treatment. Environmental Pollution. 111: 273-281.

[7] Cohen, Y. 2001. Biofiltration-the Treatment of Fluids by Microorganisms Immobilized into the Filter Bedding Material: a Review. Bioresource Technology. 77: 257-274.

[8] Turbak, A.F. 1993. Non-woven: Theory, Process, Performance and Testing. Atlanta: Tappi Press.

[9] Roy, C., R. Auger, and R, Chénier. 1998. Use of Non Woven Textile in Intermittent Filters. Water Science and Technology, 38(3): 159166.

[10] Lee, W., S. Kang, and H. Shin. 2003. Sludge Characteristics and their Contribution to Microfiltration in Submerged Membrane Bioreactors. Journal of Membrane Science. 216: 217-227.

[11] Seo, G.T., Y. Suzuki, and S. Ohgaki. 1996. Biological Powdered Activated Carbon (BPAC) Microfiltration for Wastewater Reclamation and Reuse. Desalination. 106: 39-45.

[12] American Public Health Association/ American Water Works Association/Water Environment Federation. 1998. Standard Methods for the Examination of Water and Wastewater. $20^{\text {th }}$ ed. Washington DC: APHA/AWWA/WEF. 